\title{
Upaya Peningkatan Motivasi Belajar Melalui Pembelajaran Inkuiri Teams Games Tournament
}

\author{
Nabila Yuliana ${ }^{1 *}$, Naniek Sulistya Wardani ${ }^{2}$, Tego Prastyo ${ }^{3}$ \\ 1,2,3 Pendidikan Guru Sekolah Dasar Fakultas Keguruan dan Ilmu Pendidikan Universitas Kristen Satya Wacana Salatiga, Indonesia
}

\author{
A R T I C L E I N F O \\ Article history: \\ Received 20 February \\ 2019 \\ Received in revised form \\ 10 March 2019 \\ Accepted 10 April 2019 \\ Available online 20 May \\ 2019 \\ Kata Kunci: \\ motivasi belajar \\ peningkatan, PI-TGT. \\ Keywords: \\ learning motivation, \\ improvement, PI-TGT.
}

\begin{abstract}
A B S T R A K
Penelitian ini bertujuan untuk mengetahui (1) apakah peningkatan motivasi belajar tematik dapat diupayakan melalui PI-TGT yang diterapkan pada siswa kelas II SD, (2) bagaimanakah langkahlangkah PI-TGT dapat meningkatkan motivasi belajar tematik siswa kelas II. Subyek penelitian adalah siswa kelas II sejumlah 28 siswa yang terdiri dari 9 siswa laki-laki dan 19 siswa perempuan. Jenis penelitian yang dilakukan adalah penelitian tindakan kelas (PTK). Prosedur penelitian menggunakan 2 siklus, setiap siklus terdiri dari 3 tahap yaitu, 1) perencanaan, 2) tindakan dan observasi, 3) refleksi. Teknik pengumpulan data adalah observasi dengan instrumen lembar observasi motivasi belajar. Teknik analisis data adalah teknik persentase yakni membandingkan motivasi belajar melalui PI-TGT antar siklus. Hasil penelitian terdapat peningkatan motivasi belajar, yang diupayakan melalui PI-TGT, yakni siswa yang memiliki motivasi belajar sebanyak $54 \%$ pada siklus 1 dan meningkat menjadi $77 \%$ dari seluruh siswa di siklus 2. Peningkatan motivasi belajar sebesar $25 \%$ dari seluruh siswa. Motivasi belajar meningkat melalui PI-TGT dengan langkah (1) menyimak tujuan pembelajaran, (2) menyimak materi pembelajaran, (3) membentuk 4 kelompok @7 siswa, (4) diskusi untuk mengidentifikasi
\end{abstract} masalah, (5) mempresentasikan dan memberikan tanggapan rumusan masalah, (6) mengajukan hipotesis, (7) mendemonstrasikan dalam game, (8) turnamen untuk menguji hipotesis, (9) membuat kesimpulan, dan (10) memberi penghargaan kelompok. Saran yang diberikan diharap guru dalam mendesain pembelajaran mengunakan PI-TGT agar motivasi belajar siswa meningkat.

\section{A B S T R A C T}

This study aims to determine (1) whether an increase in thematic learning motivation can be pursued through the PI-TGT applied to second grade elementary school students, (2) how can the steps of PI-TGT increase motivation in class II thematic learning. The research subjects were class II students with 28 students consisting of 9 male students and 19 female students. This type of research is classroom action research (CAR). The research procedure uses 2 cycles, each cycle consists of 3 stages, namely, 1) planning, 2) actions and observations, 3) reflection. The technique of collecting data is observation with an instrument of learning motivation observation sheet. Data analysis technique is a percentage technique that compares the motivation to learn through PI-TGT between cycles. The results of the study showed an increase in learning motivation, which was pursued through the PI-TGT, namely students who had learning motivation as much as $54 \%$ in cycle 1 and increased to $77 \%$ of all students in cycle 2. Increased learning motivation was $25 \%$ of all students. Learning motivation increases through the PI-TGT by step (1) listening to the learning objectives, (2) listening to the learning material, (3) forming 4 groups @ 7 students, (4) discussion to identify problems, (5) presenting and responding to the problem formulation, (6) submit hypotheses, (7) demonstrate in games, (8) tournaments to test hypotheses, (9) make conclusions, and (10) give group awards. Suggestions given are expected to teachers in designing learning using PI-TGT so that student learning motivation increases. 


\section{Pendahuluan}

Pendidikan merupakan pondasi bagi kemajuan bangsa. Pendidikan memegang peran yang sangat penting dalam proses peningkatan kualitas sumber daya manusia melalui berbagai usaha pembangunan pendidikan yang lebih berkualitas antara lain melalui pengembangan dan perbaikan kurikulum dan sistem evaluasi, perbaikan sarana pendidikan, pengembangan dan pengadaan materi ajar, serta pelatihan bagi guru dan tenaga kependidikan lainnya.

Pendidikan dalam proses pelaksanaannya mengacu pada Standar Kompetensi Lulusan dan Standar Isi yang mencakup sikap, pengetahuan, dan keterampilan peserta didik secara interaktif, inspiratif, menyenangkan, menantang, memotivasi peserta didik untuk berpartisipasi aktif dengan pengalaman yang bermakna.

Permendikbud Nomor 22 Tahun 2016, Madjid (2014: 49), dan Sukerti (2015: 2) disimpulkan pembelajaran tematik terpadu merupakan perpaduan beberapa aspek pembelajaran seperti mata pelajaran yang akan disampaikan kepada siswa dalam bentuk tema.

Menurut Ahmadi \& Amri (2014: 224) kelebihan pembelajaran tematik terpadu yaitu: (1) peserta didik memerlukan peluang tambahan untuk menggunakan talentanya, (2) menyediakan waktu bersama yang lain secara cepat mengkonseptualisasi dan mensintesis, (3) relevan untuk mengakomodasi kualitatif lingkungan belajar, (4) menginspirasi peserta didik untuk memperoleh pengalaman belajar, dan (5) memiliki perbedaan kualitatif dengan pembelajaran lain, karena sifatnya memandu peserta didik mencapai kemampuan berpikir tingkat tinggi atau keterampilan berpikir dengan mengoptimasi kecerdasan ganda.

Lomu (2018: 747) motivasi sangat erat hubungannya dengan kebutuhan mengaktualisasikan diri sehingga motivasi mempunyai pengaruh yang besar pada kegiatan belajar siswa terlebih yang bertujuan mencapai prestasi belajar yang tinggi. Rasa malas akan timbul kapan saja jika seseorang tidak memiliki motivasi, seperti saat pelajaran berlangsung, belajar mandiri atau individu, ataupun saat mengerjakan tugastugas dari guru. Begitupun sebaliknya dengan siswa yang memiliki motivasi belajar yang tinggi tentunya akan timbul niat untuk belajar, mengerjakan tugas-tugas, membangun niat belajar biasanya dengan memulai membuat jadual belajar dan akan melaksanakannya dengan tekun dan teratur.

Martinis Yamin (2011: 158), Uno dalam Awe (2017: 235), Sukma (2017: 115), dan Sappe (2018: 531) disimpulkan motivasi belajar adalah penggerak energi psikis yang berasal dari dorongan internal dan eksternal yang mendorong seseorang melakukan aktivitas, keterampilan, dan pengalaman pembelajaran.

Setyowati (2014: 9) fungsi motivasi belajar yaitu: (1) mendorong manusia untuk melakukan suatu aktifitas atas pemenuhan kebutuhan, (2) menentukan arah tujuan yang hendak dicapai, dan (3) menentukan perbuatan yang harus dilakukan.

Zulfikri dalam Sudiyati (2014:4) adapun jenis-jenis aktifitas kegiatan siswa pada saat proses pembelajaran berlangsung yaitu: (1) Visual Activities, segala kegiatan yang berhubungan dengan aktivitas siswa dalam melihat, mengamati, dan memperhatikan, (2) Oral Activities, aktivitas yang berhubungan dengan kemampuan siswa dalam mengucapkan, melafazkan, dan berfikir, (3) Listening Activities, aktivitas yang berhubungan dengan kemampuan siswa dalam berkonsentrasi menyimak pelajaran, dan (4) Motor Activities, segala keterampilan jasmani siswa untuk mengekspresikan bakat yang dimilikinya.

Suprihatiningrum (2014: 63), Octavany (2018: 227), Ananda (2016: 38) dan Puspita (2018: 245) disimpulkan pembelajaran inkuiri yaitu pembelajaran yang melibatkan partisipasi aktif siswa untuk mencari dan menemukan sendiri jawabannya. Hal ini didukung dengan hasil penelitian yang dilakukan Dewi Retno (2014) tentang peningkatan motivasi belajar terbukti dengan adanya peningkatan motivasi belajar pada siklus 1 yakni sebesar 73,61\% dan pada siklus 2 meningkat menjadi 92,44\%. Rahmani, dkk (2015) tentang peningkatan motivasi belajar terbukti dengan hasil perhitungan untuk motivasi belajar siswa diperoleh thitung=7,427 sedangkan nilai ttabel=1,6827 dimana thitung $>$ ttabel.

Ananda (2016: 39), Sanjaya, Wina dalam Santoso (2014: 7), dan Setyowati (2014: 14) disimpulkan langkah-langkah dalam pembelajaran inkuiri yaitu: (1) identifikasi masalah, (2) merumuskan masalah, (3) mengajukan hipotesis, (4) mengumpulkan data, (5) uji hipotesis dan (6) kesimpulan.

Kelebihan pembelajaran inkuiri yaitu: (1) model pengajaran menjadi berubah dari yang bersifat penyajian informasi menjadi pengolahan informasi, (2) pengajaran berubah dari teacher centered menjadi student centered guru lebih banyak membimbing, (3) dapat membentuk dan mengembangkan self-concept pada diri siswa, (4) dapat memperkaya dan memperdalam materi yang dipelajari, sehingga tahan lama dalam ingatan, (5) memungkinkan siswa belajar dengan memanfaatkan berbagai jenis sumber belajar dan tidak hanya menjadikan guru sebagai satu-satunya sumber belajar, dan (6) menghindarkan cara belajar tradisional (menghafal). 
Huda (2014: 197), Aryati (2018: 2), Aryati (2018: 6), Ardian dalam Aryati (2018: 35), Setiawan (2018: 216) disimpulkan Teams Games Tournament (TGT) merupakan model pembelajaran dengan kelompok-kelompok melakukan permainan untuk berkompetisi dalam pemecahan masalah terkait materi pembelajaran. Hal ini didukung dengan hasil penelitian yang dilakukan Dani Muhammad Darmawan (2017) tentang peningkatan motivasi belajar terbukti peningkatan motivasi belajar pada siklus 73,7\% dan terjadi peningkatan pada siklus 2 yaitu 83,2\%. Lesmana dan Suarjana (2017) tentang peningkatan motivasi belajar terbukti peningkatan motivasi belajar pada siklus 1 adalah $69,8 \%$ pada siklus 2 meningkat menjadi $84,11 \%$.

Aryati (2018: 6), Prasetianty (2014: 13), dan Komalasari (2010: 67) disimpulkan langkah-langkah model pembelajaran kooperatif tipe TGT yaitu: (1) menyimak tujuan pembelajaran, (2) menyimak materi pembelajaran, (3) membentuk 4 kelompok @ 4 siswa, (4) diskusi Lembar Kerja Peserta Didik (LKPD), (5) presentasi, (6) game untuk menjawab pertanyaan (7) turnamen, dan (8) penghargaan kelompok.

Yuni (2016: 6) kelebihan model pembelajaran kooperatif tipe TGT adalah yaitu: (1) siswa memiliki kebebasan untuk berinteraksi dan menggunakan pendapat, (2) rasa percaya diri yang dimiliki siswa menjadi lebih tinggi, (3) perilaku mengganggu terhadap siswa lain menjadi lebih kecil, (4) motivasi belajar siswa bertambah, (5) pemahaman yang lebih mendalam terhadap materi pelajaran, (6) meningkatkan kebaikan budi, kepekaan, dan toleransi baik antar siswa maupun antar siswa dengan guru, dan (7) dapat mengembangkan seluruh potensi yang ada dalam diri, selain itu dengan kerja sama akan membuat interaksi belajar dalam kelas menjadi hidup dan tidak membosankan.

Motivasi belajar siswa diupayakan terjadi peningkatan dengan pembelajaran menggunakan pembelajaran PI-TGT. Pembelajaran Inkuiri TGT atau yang disingkat sebagai (PI-TGT) yaitu kegiatan pembelajaran yang melibatkan partisipasi aktif siswa secara berkelompok untuk mencari dan menemukan sendiri jawabannya dalam permainan untuk berkompetisi.

Langkah PI-TGT dapat disimpulkan yaitu: (1) menyimak tujuan pembelajaran, (2) menyimak materi pembelajaran, (3) membentuk 4 kelompok @7 siswa, (4) diskusi untuk mengidentifikasi masalah, (5) mempresentasikan dan memberikan tanggapan rumusan masalah, (6) mengajukan hipotesis, (7) mendemonstrasikan dalam game, (8) turnamen untuk menguji hipotesis, (9) membuat kesimpulan, dan (10) memberi penghargaan kelompok.

Berdasarkan paparan diatas, perlunya dilakukan penelitian ini adalah: (1) untuk mengetahui apakah peningkatan motivasi belajar tematik dapat diupayakan melalui PI-TGT yang diterapkan pada siswa kelas II SD tahun pelajaran 2018/2019, (2) untuk mengetahui bagaimanakah langkah-langkah PITGT dapat meningkatkan motivasi belajar tematik siswa kelas II SDN Gendongan 03 Salatiga semester II tahun pelajaran 2018/2019. Skema tentang peningkatan motivasi belajar menggunakan PI-TGT secara lebih dapat disajikan melalui gambar 1 sebagai berikut. 


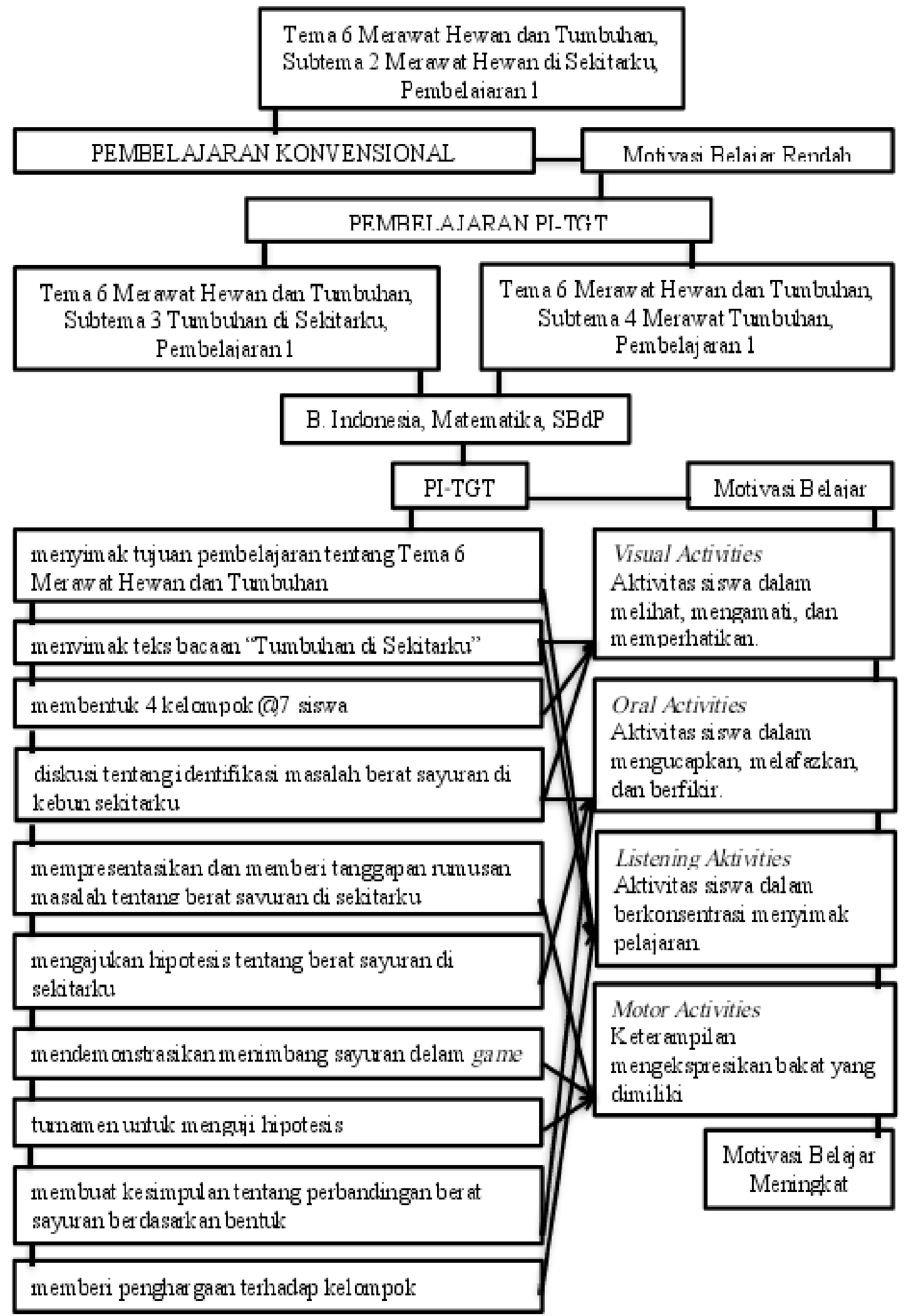

Gambar 1 Upaya Peningkatan Motivasi Belajar Tema 6 "Merawat Hewan dan Tumbuhan" Subtema 3 dan 4 melalui PI-TGT

Hipotesis penelitian ini adalah peningkatan motivasi belajar Tema 6 Merawat Hewan dan Tumbuhan, Subtema 3 Tumbuhan di Sekitarku, Pembelajaran 1 diduga dapat diupayakan melalui PI-TGT siswa kelas II SDN Gendongan 02 Salatiga semester 2 tahun pelajaran 2018/2019. 


\section{Metode}

PTK ini dilaksanakan di SDN Gendongan 03 semester 2 tahun pelajaran 2018/2019. Subyek penelitian adalah siswa kelas II sebanyak 28 siswa, yang terdiri dari 9 siswa laki-laki dan 19 siswa perempuan. Penelitian ini terdapat dua variabel yaitu motivasi belajar dan PI-TGT. Motivasi belajar adalah diukur melalui aktifitas kegiatan siswa pada saat proses pembelajaran berlangsung sebagai berikut: (1) Visual Activities, segala kegiatan yang berhubungan dengan aktivitas siswa dalam melihat, mengamati, dan memperhatikan, (2) Oral Activities, aktivitas yang berhubungan dengan kemampuan siswa dalam mengucapkan, melafazkan, dan berfikir. (3) Listening Activities, aktivitas yang berhubungan dengan kemampuan siswa dalam berkonsentrasi menyimak pelajaran, (4) Motor Activities, segala keterampilan jasmani siswa untuk mengekspresikan bakat yang dimilikinya.

PI-TGT pada masalah tema 6 Merawat Hewan dan Tumbuhan, subtema 3 Tumbuhan di Sekitarku dengan cara: 1) menyimak tujuan pembelajaran tentang tema 6 Merawat Hewan dan Tumbuhan, 2) menyimak teks bacaan "Tumbuhan di Sekitarku", 3) membentuk kelompok @7 siswa, 4) diskusi tentang identifikasi masalah berat sayuran di sekitarku, 5) mempresentasikan dan memberi tanggapan rumusan masalah tentang berat sayuran di sekitarku, 6) mengajukan hipotesis tentang berat berat sayuran di sekitarku, 7) mendemonstrasikan menimbang sayuran dalam game, 8) turnamen untuk menguji hipotesis, 9) membuat kesimpulan tentang perbandingan berat sayuran berdasarkan bentuk, dan 10) memberikan penghargaan terhadap kelompok.

Jenis penelitian ini adalah PTK dengan prosedur PTK minimal 2 siklus. Setiap siklus terdiri dari 3 tahap yaitu, 1) perencanaan, 2) tindakan dan observasi, 3) refleksi. Model PTK menggunakan model spiral oleh Mc. Taggart. Secara lebih rinci dapat dilihat pada gambar 2 sebagai berikut:

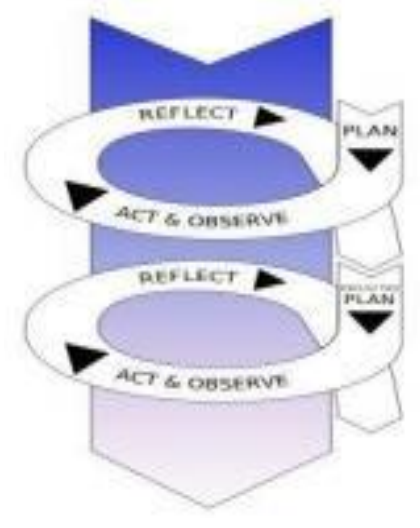

Gambar 2. PTK Model Spiral Stephen Kemmis dan Robin Mc. Taggard

Teknik pengumpulan data yang digunakan dalam penelitian ini adalah teknik non tes yang berbentuk unjuk kerja dengan instrumen penilaian lembar observasi motivasi belajar. Penelitian ini dikatakan berhasil, jika jumlah siswa yang termotivasi belajar mencapai $\geq 80 \%$ dari seluruh siswa.

\section{Hasil dan Pembahasan}

Peningkatan peningkatan motivasi belajar siswa kelas II SDN Gendongan 02 Salatiga semester 2 tahun pelajaran 2018/2019 diupayakan melalui desain PI-TGT. PI-TGT dilakukan melalui 2 siklus, masing-masing siklus terdiri dari 3 tahap yaitu perencanaan, pelaksanaan tindakan dan observasi, serta refleksi.

Tahap ke 1 adalah perencanaan pembelajaran siklus 1 dengan menyusun RPP tema 6 Merawat Hewan dan Tumbuhan, subtema 2 Tumbuhan di Sekitarku, pembelajaran 1 untuk kelas II semester 2 tahun pelajaran 2018/2019 SDN Gendongan 03 Salatiga. Pembelajaran siklus 1 terdapat 3 muatan pelajaran yatiu B. Indonesia dengan KD 3.7 Mencermati tulisan tegak bersambung dalam cerita dengan memperhatikan penggunaan huruf kapital (awal kalimat, nama bulan dan hari, nama orang) serta mengenal tanda titik pada kalimat berita dan tanda tanya pada kalimat tanya. KD 4.7 Menulis dengan tulisan tegak bersambung menggunakan huruf kapital (awal kalimat, nama bulan, hari, dan nama diri) serta tanda titik pada kalimat berita dan tanda tanya pada kalimat tanya dengan benar. Matematika dengan KD 3.6 Menjelaskan dan menentukan panjang (termasuk jarak), berat, dan waktu dalam satuan baku, yang berkaitan dengan kehidupan sehari-hari. KD 4.6 Melakukan pengukuran panjang (termasuk 
jarak), berat, dan waktu dalam satuan baku, yang berkaitan dengan kehidupan sehari-hari. SBdP dengan KD 3.1 Mengenal karya imajinatif dua dan tiga dimensi. KD 4.1 Membuat karya imajinatif dua dan tiga dimensi.

Perencanaan siklus 1 selain menyusun RPP, juga menyiapkan perangkat pembelajaran yang berupa materi satuan berat benda di sekitarku, menyiapkan media pembelajaran berupa timbangan dan plastisin, membuat kisi-kisi pengukuran motivasi belajar, dan membuat rubrik pengukuran motivasi belajar.

Tahap ke 2 adalah pelaksanaan tindakan dan observasi. Dalam kegiatan ini, guru melaksanakan pembelajaran sesuai dengan RPP yang telah disiapkan. Dalam pelaksanaan pembelajaran, dilakukan observasi oleh teman sejawat untuk mengecek apakah pelaksanaan pembelajaran sesuai dengan RPP yang telah dirancang.

Kegiatan belajar siswa terdiri dari kegiatan pendahuluan, kegiatan inti dan kegiatan penutup. Kegiatan pendahuluan terdiri dari apersepsi dan penjelasan tujuan pembelajaran. Kegiatan inti terdiri dari langkah PI-TGT dan kegiatan penutup berisi tentang membuat kesimpulan.

Pada kegiatan inti, siswa melaksanakan kegiatan pembelajaran dengan indikator pengukuran motivasi belajar. Pelaksanaan PI-TGT bersamaan dengan kegiatan observasi pengukuran motivasi belajar yang dilakukan oleh observer yaitu guru kelas dengan berpedoman rubrik pengukuran motivasi belajar. Observasi pengukuran motivasi belajar pada pembelajaran PI-TGT bertujuan untuk mengukur motivasi belajar siswa. Hasil dari motivasi belajar siswa tema 6 Merawat Hewan dan Tumbuhan, subtema 2 Tumbuhan di Sekitarku, pembelajaran 1 secara lebih rinci dapat dilihat pada Tabel 1 sebagai berikut:

Tabel 1. Motivasi Belajar Berdasarkan Aktivitas Siswa Siklus 1

\begin{tabular}{|c|c|c|c|c|c|c|c|c|c|c|c|c|c|c|c|c|}
\hline \multirow{2}{*}{$\begin{array}{l}\text { Aspek } \\
\text { Indikator }\end{array}$} & \multicolumn{6}{|c|}{ Visual Activities } & \multirow{2}{*}{\multicolumn{2}{|c|}{ Jumlah }} & \multicolumn{6}{|c|}{ Oral Activities } & \multirow{2}{*}{\multicolumn{2}{|c|}{ Jumlah }} \\
\hline & 1 & & 2 & & 3 & & & & 4 & & 5 & & 6 & & & \\
\hline Skor & $\mathrm{F}$ & $\%$ & $\mathrm{~F}$ & $\%$ & $\mathrm{~F}$ & $\%$ & $\mathrm{~F}$ & $\%$ & $\mathrm{~F}$ & $\%$ & $\mathrm{~F}$ & $\%$ & $\mathrm{~F}$ & $\%$ & $\mathrm{~F}$ & $\%$ \\
\hline 1 & 25 & 89 & 21 & 75 & 18 & 64 & 21 & 76 & 19 & 68 & 16 & 57 & 10 & 36 & 15 & 54 \\
\hline 0 & 3 & 11 & 7 & 25 & 10 & 36 & 7 & 24 & 9 & 32 & 12 & 43 & 18 & 64 & 13 & 46 \\
\hline Jumlah & 28 & 100 & 28 & 100 & 28 & 100 & 28 & 100 & 28 & 100 & 28 & 100 & 28 & 100 & 28 & 100 \\
\hline Aspek & \multicolumn{6}{|c|}{ Listening Activities } & \multirow{2}{*}{\multicolumn{2}{|c|}{ Jumlah }} & \multicolumn{6}{|c|}{ Motor Activities } & \multirow{2}{*}{\multicolumn{2}{|c|}{ Jumlah }} \\
\hline Indikator & 7 & & 8 & & 9 & & & & 10 & & 11 & & 12 & & & \\
\hline Skor & $\mathrm{F}$ & $\%$ & $\mathrm{~F}$ & $\%$ & $\mathrm{~F}$ & $\%$ & $\mathrm{~F}$ & $\%$ & $\mathrm{~F}$ & $\%$ & $\mathrm{~F}$ & $\%$ & $F$ & $\%$ & $\mathrm{~F}$ & $\%$ \\
\hline 1 & 15 & 54 & 17 & 61 & 21 & 75 & 18 & 68 & 12 & 43 & 27 & 96 & 19 & 68 & 19 & 69 \\
\hline 0 & 13 & 46 & 11 & 39 & 7 & 25 & 10 & 37 & 16 & 57 & 1 & 4 & 9 & 32 & 9 & 31 \\
\hline Jumlah & 28 & 100 & 28 & 100 & 28 & 100 & 28 & 100 & 28 & 100 & 28 & 100 & 28 & 100 & 28 & 100 \\
\hline
\end{tabular}

Sumber: Data primer

Keterangan: F= Frekuensi, \%= Persentase

Indikator 1= menyimak identifikasi masalah berat sayuran, $2=$ ikut serta melakukan pengukuran sayuran (cabai, tomat, ubi dan kentang) dalam kelompok, $3=$ mencatat hasil pengukuran kelompok tentang berat sayuran (cabai, tomat, ubi dan kentang), 4= mengajukan rumusan masalah berat sayuran (cabai, tomat, ubi dan kentang) secara lisan, 5= menyampaikan cara menentukan berat sayuran (cabai, tomat, ubi dan kentang) saat berdiskusi, $6=$ menyampaikan kesimpulan tentang berat sayuran (cabai, tomat, ubi dan kentang) secara lisan, $7=$ menyebutkan kembali tujuan pembelajaran Tema 6 Merawat Hewan dan Tumbuhan, Subtema 3 Tumbuhan di Sekitarku, Pembelajaran 1, 8= menyebutkan kembali penjelasan guru tentang perbandingan berat sayuran (cabai, tomat, ubi dan kentang), $9=$ menjelaskan kembali paparan teman tentang hasil diskusi berat sayuran (cabai, tomat, ubi dan kentang), $10=$ berbicara dengan lancar saat menyampaikan hasil diskusi tentang perbandingan berat sayuran (cabai, tomat, ubi dan kentang), 11= terampilan menimbang berat sayuran (cabai, tomat, ubi dan kentang) menggunakan timbangan jarum, 12= menjawab pertanyaan dengan lancar tentang perbandingan berat sayuran (cabai, tomat, ubi dan kentang).

Tabel 1 menunjukkan persentase motivasi belajar pada aspek: 1) visual activities sebesar 76\%, 2) oral activities sebesar 54\%,3) listening activities sebesar 63\%, dan motor activities sebesar 69\%. Persentase motivasi belajar tertinggi pada aspek visual activities sebesar $76 \%$, dengan perolehan indikator 1 sebesar 89\% dari 25 siswa, indikator 2 sebesar 75\% dari 21 siswa, indikator 3 sebesar 64\% dari 18 siswa. Persentase motivasi belajar terendah pada aspek oral activities sebesar 54\%, dengan perolehan indikator 4 sebesar $68 \%$ dari 19 siswa, indikator 5 sebesar 57\% dari 16 siswa, indikator 6 sebesar 36\% dari 10 siswa. 
Kegiatan PI-TGT pada siklus 2 perlu diadakan perbaikan berdasarkan persentase motivasi belajar siswa dengan menggunakan kegiatan PI-TGT pada siklus 1 motivasi belajar belum mencapai $\geq 80 \%$ pada seluruh siswa.

Kegiatan penutup, siswa melaksanakan refleksi pembelajaran dengan guru bertanya kepada siswa tentang materi satuan berat benda disekitarku, selanjutnya salah satu dari siswa memimpin doa untuk mengakhiri pembelajaran.

Tahap ke 3 adalah refleksi yang bertujuan untuk menilai kelebihan dan kelemahan saat melaksanakan pembelajaran siklus 1. Kelebihan pembelajaran siklus 1 adalah siswa aktif dalam mengikuti pembelajaran serta media pembelajaran berupa plastisin dan timbangan membantu siswa memahami materi pembelajaran. Kelemahan pembelajaran siklus 1 adalah saat kegaduhan yang terjadi ketika membentuk 4 kelompok beranggotakan 7 siswa serta kegiatan demonstrasi menggunakan timbangan yang membuat siswa berebut untuk menggunakan.

Tindakan yang dilakukan berdasarkan RPP dengan desain PI-TGT akan dnilai berdasarkan lembar observasi yang tersedia. Observasi yang dilakukan pada siklus 1 telah dijadikan acuan perbaikan pada saat siklus 2, sehingga terlihat peningkatan yang terjadi secara lebih rinci dapat dilihat pada Tabel 2 sebagai berikut:

Tabel 2. Motivasi Belajar Berdasarkan Aktivitas Siswa Siklus 2

\begin{tabular}{|c|c|c|c|c|c|c|c|c|c|c|c|c|c|c|c|c|}
\hline \multirow{2}{*}{$\begin{array}{l}\text { Aspek } \\
\text { Indikator }\end{array}$} & \multicolumn{6}{|c|}{ Visual Activities } & \multirow{2}{*}{\multicolumn{2}{|c|}{ Jumlah }} & \multicolumn{6}{|c|}{ Oral Activities } & \multirow{2}{*}{\multicolumn{2}{|c|}{ Jumlah }} \\
\hline & \multicolumn{2}{|c|}{1} & \multicolumn{2}{|c|}{2} & \multicolumn{2}{|l|}{3} & & & \multicolumn{2}{|c|}{4} & \multicolumn{2}{|l|}{5} & \multicolumn{2}{|l|}{6} & & \\
\hline Skor & $\mathrm{F}$ & $\%$ & $\mathrm{~F}$ & $\%$ & $\mathrm{~F}$ & $\%$ & $\mathrm{~F}$ & $\%$ & $\mathrm{~F}$ & $\%$ & $\mathrm{~F}$ & $\%$ & $\mathrm{~F}$ & $\%$ & $\mathrm{~F}$ & $\%$ \\
\hline 1 & 26 & 93 & 27 & 96 & 20 & 71 & 24 & 87 & 20 & 71 & 24 & 86 & 21 & 75 & 22 & 77 \\
\hline 0 & 2 & 7 & 1 & 4 & 8 & 29 & 4 & 13 & 8 & 29 & 4 & 14 & 7 & 25 & 6 & 23 \\
\hline Jumlah & 28 & 100 & 28 & 100 & 28 & 100 & 28 & 100 & 28 & 100 & 28 & 100 & 28 & 100 & 28 & 100 \\
\hline Aspek & \multicolumn{6}{|c|}{ Listening Activities } & \multirow{2}{*}{\multicolumn{2}{|c|}{ Jumlah }} & \multicolumn{6}{|c|}{ Motor Activities } & \multirow{2}{*}{\multicolumn{2}{|c|}{ Jumlah }} \\
\hline Indikator & 7 & & 8 & & 9 & & & & 10 & & 11 & & 12 & & & \\
\hline Skor & $F$ & $\%$ & $F$ & $\%$ & $\mathrm{~F}$ & $\%$ & $F$ & $\%$ & $F$ & $\%$ & $F$ & $\%$ & $F$ & $\%$ & $F$ & $\%$ \\
\hline 1 & 22 & 79 & 22 & 79 & 19 & 68 & 21 & 75 & 20 & 71 & 28 & 100 & 20 & 71 & 23 & 81 \\
\hline 0 & 6 & 21 & 6 & 21 & 9 & 32 & 7 & 25 & 8 & 29 & 0 & 0 & 8 & 29 & 5 & 19 \\
\hline Jumlah & 28 & 100 & 28 & 100 & 28 & 100 & 28 & 100 & 28 & 100 & 28 & 100 & 28 & 100 & 28 & 100 \\
\hline
\end{tabular}

Sumber: Data primer

Keterangan: (Sama dengan Tabel 1)

Tabel 2 menunjukkan persentase motivasi belajar pada aspek: 1) visual activities sebesar 87\%, 2) oral activities sebesar 77\%, 3) listening activities sebesar 75\%, dan motor activities sebesar $81 \%$. Persentase motivasi belajar tertinggi pada aspek visual activities sebesar 87\%, dengan perolehan indikator 1 sebesar 93\% dari 26 siswa, indikator 2 sebesar 96\% dari 27 siswa, indikator 3 sebesar $71 \%$ dari 20 siswa. Persentase motivasi belajar terendah pada aspek listening activities sebesar 75\%, dengan perolehan indikator 7 sebesar 79\% dari 22 siswa, indikator 8 sebesar $79 \%$ dari 22 siswa, indikator 9 sebesar $68 \%$ dari 19 siswa.

Hasil penelitian dapat dinyatakan berhasil berdasarkan perbandingan hasil presentasi motivasi belajar siklus 1 dan siklus 2. Secara lebih rinci dapat dilihat dari Tabel 3 sebagai berikut:

Tabel 3. Perbandingan Persentase Motivasi Belajar Siklus 1 dan Siklus 2

\begin{tabular}{llll}
\hline Aspek & Siklus 1 & Siklus 2 & Persentase Peningkatan \\
\hline Visual Activities & $76 \%$ & $87 \%$ & $11 \%$ \\
Oral Activities & $54 \%$ & $77 \%$ & $23 \%$ \\
Listening Activities & $63 \%$ & $75 \%$ & $12 \%$ \\
Motor Activities & $69 \%$ & $81 \%$ & $12 \%$ \\
\hline
\end{tabular}

Tindakan pembelajaran PI-TGT dapat meningkatan motivasi belajar siswa yang ditunjukkan oleh besarnya persentase motivasi belajar pada aspek Visual Activities sebesar 76\% pada siklus 1 dan meningkat menjadi 87\% di siklus 2, persentase peningkatan sebesar 11\%. Aspek Oral Activities sebesar 54\% pada siklus 1 dan meningkat menjadi 77\% di siklus 2, persentase peningkatan sebesar 23\%. Aspek Listening Activities sebesar 63\% pada siklus 1 dan meningkat menjadi $75 \%$ di siklus 2 , persentase 
peningkatan sebesar 12\%. Aspek Motor Activities sebesar 69\% pada siklus 1 dan meningkat menjadi 81\% di siklus 2, persentase peningkatan sebesar $12 \%$.

Peningkatan motivasi belajar tertinggi pada aspek Oral Activities dengan peningkatan sebesar 23\%. Oral Activities dengan 3 indikator yaitu mengajukan rumusan masalah berat sayuran (cabai, tomat, ubi dan kentang) secara lisan dengan perolehan skor pada siklus 1 sebesar $68 \%$ dari 19 siswa meningkat menjadi $71 \%$ dari 20 pada siklus 2 persentase peningkatan sebesar $3 \%$. Indikator menyampaikan cara menentukan berat sayuran (cabai, tomat, ubi dan kentang) saat berdiskusi, dengan perolehan skor pada siklus 1 sebesar $57 \%$ dari 16 siswa meningkat menjadi 86\% dari 24 pada siklus 2 persentase peningkatan sebesar 29\%. Indikator menyampaikan kesimpulan tentang berat sayuran (cabai, tomat, ubi dan kentang) secara lisan, dengan perolehan skor pada siklus 1 sebesar 36\% dari 10 siswa meningkat menjadi $75 \%$ dari 21 pada siklus 2 persentase peningkatan sebesar 39\%.

Perbandingan motivasi belajar pada 12 indikator pada siklus 1 dan siklus 2 secara lebih rinci dapat dilihat dari perbandingan kurva persentase sebagai berikut:

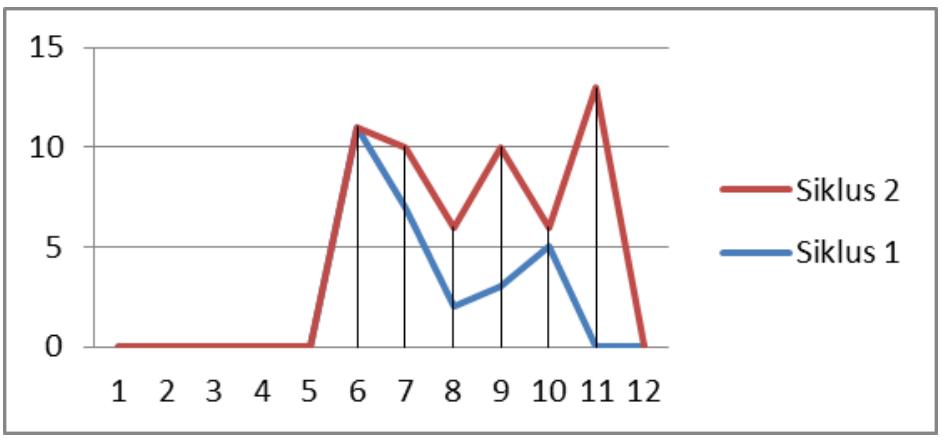

Gambar 3 Perbandingan Kurva Persentase Motivasi Belajar Siklus 1 dan Siklus 2

Hasil penelitian sejalan dengan penelitian yang dilakukan oleh Dewi Retno (2014) berjudul "Penggunaan Model Pembelajaran Inkuiri Terbimbing (Guided Inquiry) untuk Meningkatkan Motivasi Belajar dan Hasil Belajar IPA Kelas IV di SDN Gendongan 01 Semester II Tahun Pelajaran 2013/2014". Temuan yang diperoleh meningkatnya motivasi belajar diukur melalui 2 jenis motivasi yaitu 1) motivasi intrinsik, dan 2) motivasi ekstrinsik. Teknik pengumpulan data melalui angket dan data diolah dengan analisis statistik deskriptif dan deskriptif kuantitatif.Terbukti dengan adanya peningkatan motivasi belajar pada siklus 1 yakni sebesar 73,61\% dan pada siklus 2 meningkat menjadi 92,44\%.

Penelitian lain yang sejalan yaitu penelitian yang dilakukan oleh Dani Muhammad Darmawan (2017) berjudul "Upaya Meningkatkan Motivasi dan Hasil Belajar IPA melalui Model Pembelajaran Kooperatif Tipe Teams Game Tournament (TGT) pada Siswa Kelas V SD N Pendem Pengasih Kabupaten Kulon Progo". Temuan yang diperoleh meningkatnya motivasi belajar diukur melalui 5 indikator yaitu 1) ingin mempelajari IPA, 2) senang belajar IPA, 3) tekun menghadapi tugas, 4) senang mencari dan memecahkan soal-soal IPA, dan 5) ulet menghadapi tugas. Teknik pengumpulan data melalui lembar observasi dan data diolah dengan analisis persentase. Terbukti peningkatan motivasi belajar pada siklus 1 sebesar $73,7 \%$ dan terjadi peningkatan pada siklus 2 yaitu $83,2 \%$.

Penelitian lain yang sejalan yaitu penelitian yang dilakukan oleh Lesmana dan Suarjana (2017) berjudul "Peningkatan Motivasi Belajar Siswa melalui Penerapan Model Pembelajaran TGT". Temuan yang diperoleh meningkatnya motivasi belajar diukur melalui 6 indikator yaitu 1) adanya hasrat dan keinginan untuk berhasil, 2) adanya dorongan dan kebutuhan dalam belajar, 3) adanya harapan dan cita-cita masa depan, 4) adanya penghargaan dalam belajar, 5) adanya kegiatan yang menarik dalam belajar, 6) adanya lingkungan belajar yang kondusif sehingga memungkinkan peserta didik untuk dapat belajar dengan baik. Teknik pengumpulan data melalui angket dan data diolah dengan analisis statistik deskriptif dan deskriptif kuantitatif.Terbukti peningkatan motivasi belajar pada siklus 1 adalah 69,8\% pada siklus 2 meningkat menjadi $84,11 \%$.

\section{Simpulan Dan Saran}

Simpulan penelitian ini adalah terdapat peningkatan motivasi belajar melalui PI-TGT. Peningkatan motivasi belajar ditunjukkan melalui besarnya persentase siswa yang mencapai motivasi belajar pada siklus 1 yakni motivasi belajar sebanyak 74,29\% dari seluruh siswa pada siklus 1 dan meningkat menjadi 96,07\% dari seluruh siswa di siklus 2. Selisih antara siklus 1 ke siklus 2 mencapai 21,78\% dari seluruh siswa. Motivasi belajar meningkat melalui PI-TGT dengan langkah (1) menyimak tujuan pembelajaran, 
(2) menyimak materi pembelajaran, (3) membentuk 4 kelompok @7 siswa, (4) diskusi untuk mengidentifikasi masalah, (5) mempresentasikan dan memberikan tanggapan rumusan masalah, (6) mengajukan hipotesis, (7) mendemonstrasikan dalam game, (8) turnamen untuk menguji hipotesis, (9) membuat kesimpulan, dan (10) memberi penghargaan kelompok. Saran yang dapat diajukan penggunaan pembelajaran PI-TGT dapat dipertimbangkan guru untuk diterapkan untuk meningkatkan motivasi belajar siswa

\section{Daftar Rujukan}

Ahmadi, I.K., \& Amri, S. 2014. Pengembangan \& Model Pembelajaran Tematif Integratif. Jakarta: Prestasi Pustaka Publisher.

Ananda, T., \& Putri, H. E. (2016). PENERAPAN PEMBELAJARAN INKUIRI DALAM PEMBELAJARAN MATEMATIKA DI SEKOLAH DASAR. Metodik Didaktik, 10(2).

Aryati, D., Usman, U., \& Majid, A. (2018). PENGARUH PENGGUNAAN MODEL PEMBELAJARAN MAKE A MATCH DALAM MODEL PEMBELAJARAN TEAMS GAMES TOURNAMENT TERHADAP HASIL BELAJAR SISWA SMA PADA POKOK BAHASAN TATA NAMA SENYAWA. Bivalen: Chemical Studies Journal, 1(1), 1-4.

Awe, E. Y., \& Benge, K. (2017). HUBUNGAN ANTARA MINAT DAN MOTIVASI BELAJAR DENGAN HASIL BELAJAR IPA PADA SISWA SD. Journal of Education Technology, 1(4), 231-238.

Darmawan, Dani Muhammad. (2017) UPAYA MENINGKATKAN MOTIVASI DAN HASIL BELAJAR IPA MELALUI MODEL PEMBELAJARAN KOOPERATIF TIPE TEAMS GAME TOURNAMENT (TGT) PADA SISWA KELAS V SD N PENDEM PENGASIH KABUPATEN KULON PROGO. S1 thesis, PGSD.

Dewi, Y. A. S. (2014). Upaya Meningkatkan Motivasi dan Hasil Belajar Siswa pada Pembelajara Matematika dengan Model Pembelajaran Kooperatif Tipe Numbered Heads Together (NHT) pada Siswa Kelas IV Semester II SD Negeri Lemahireng 02 Kecamatan Bawen Tahun Ajaran 2013/2014(Doctoral dissertation, Program Studi Pendidikan Guru Sekolah Dasar FKIP-UKSW).

Honan, M. 2014. Pembelajaran Saintifik dan Kontekstual dalam Pembelajaran Abad 21. Bogor: Ghalia.

Huda, M. 2011. Cooperative Learning: Metode, Teknik, Struktur dan Model Penerapan. Yogyakarta: Pustaka Pelajar.

Komalasari, Kokom. 2010. Pembelajaran Kontekstual Konsep dan Aplikasi. Bandung :PT Refika Aditama.

Lesmana, K. D., \& Suarjana, I. M. (2017). PENINGKATAN MOTIVASI BELAJAR SISWA MELALUI PENERAPAN MODEL PEMBELAJARAN TGT. Jurnal Penelitian dan Pengembangan Pendidikan, 1(2).

Lomu, L., \& Widodo, S. A. (2018, February). PENGARUH MOTIVASI BELAJAR DAN DISIPLIN BELAJAR TERHADAP PRESTASI BELAJAR MATEMATIKA SISWA. In Prosiding Seminar Nasional Pendidikan Matematika Etnomatnesia.

Madjid, Abdul (2014).Pembelajaran Tematik-Terpadu. Bandung: Remaja Rosdakarya. Permendikbud RI Nomor 67 Tahun 2013 tentang Kerangka Dasar dan Struktur Kurikulum Sekolah Dasar / Madrasah Ibtidaiyah

Nuraini , Nuraini and Karjiati, Karjiati and Dalifa, Dalifa (2013) UPAYA MENINGKATKAN AKTIVITAS DAN HASIL BELAJAR SISWA TENTANG PERKALIAN DAN PEMBAGIAN MELALUI METODE DISKUSI KELOMPOK DENGAN MENGGUNAKAN ALAT PERAGA NERACA BILANGAN (Penelitian Tindakan Kelas Pembelajaran Matematika Pada Kelas II SDN 14 Curup Kota Kabupaten Rejang Lebong). Undergraduated thesis, Fakultas 
Keguruan dan Ilmu Pendidikan Universitas Bengkulu.Octavany, Yohana. (2018). EFEKTIVITAS PENDEKATAN INKUIRI DAN MODEL JIGSAW (PI-MJ) TERHADAP MINAT BELAJAR SISWA KELAS 4 SD. Jurnal Pendidikan Berkarakter. Vol 1, No 1.

Permendikbud RI Nomor 20 Tahun 2016 tentang Standar Kelulusan Pendidikan Dasar dan Menengah. Permendikbud RI Nomor 22 Tahun 2016 tentang Standar Proses Pendidikan Dasar dan Menengah. Permendikbud RI Nomor 22 Tahun 2016 tentang Tematik Terpadu.

Prasetianty, I. S. (2014). Upaya Meningkatkan Motivasi dan Hasil Belajar IPA dengan Menggunakan Model Pembelajaran Kooperatif Tipe TGT (Teams Games Tournaments) pada Siswa Kelas 4 SDN 1 Dologan Karanggede Kabupaten Boyolali Semester II Tahun Pelajaran 2013/2014 (Doctoral dissertation, Program Studi Pendidikan Guru Sekolah Dasar FKIP- UKSW).

Puspita, E. W., Sunarno, W., \& Sarwanto, S. (2018). PEMBELAJARAN FISIKA DENGAN PEMBELAJARAN INKUIRI MELALUI METODE EKSPERIMEN DAN DEMONSTRASI DITINJAU DARI KREATIVITAS DAN MOTIVASI BERPRESTASI SISWA. INKUIRI Jurnal Pendidikan IPA, 7(2), 243-251.

Santoso, T. B. (2014). Upaya Meningkatkan Minat Belajar Siswa dan Hasil Belajar IPS Melalui Pendekatan Inkuiri Siswa Kelas 4 SDN Ringin Harjo 01 Kecamatan Gubug Kabupaten Grobogan Semester II Tahun 2013/2014 (Doctoral dissertation, Program Studi Pendidikan Guru Sekolah Dasar FKIPUKSW).

Sappe, I., Ernawati, E., \& Irmawanty, I. (2018). Hubungan Motivasi Belajar Terhadap Hasil Belajar Ipa Siswa Kelas V sdn 231 Inpres Kapunrengan Kecamatan Mangarabombang Kabupaten takalar. JKPD: Jurnal Kajian Pendidikan Dasar, 3(2), 530-539

Setiawan, W. D., \& Sugijanto, A. (2018). Pengaruh Penggunaan Model Pembelajaran Kooperatif Tipe Teams Games Tournament dan Model Pembelajaran Ekspositori terhadap Hasil Belajar Pendidikan Kewarganegaraan. TRIHAYU Jurnal Pendidikan Ke-SD-an, 4(1).

Setyowati, D. R. (2014). Penggunaan Model Pembelajaran Inkuiri Terbimbing (Guided Inquiry) untuk Meningkatkan Motivasi Belajar dan Hasil Belajar IPA Kelas IV di SD Negeri Gendongan 01 Semester II Tahun Pelajaran 2013/2014(Doctoral dissertation, Program Studi Pendidikan Guru Sekolah Dasar FKIP-UKSW).

Sudiyati. (2014). Peningkatan Aktivitas Pembelajaran Matematika dengan Pendekatan Cooperaive Learning pada Siswa Kelas I SDN 18 Kembayan. Jurnal Pendidikan dan Pembelajaran, Vol 3, No 1.

Sukma, E. S. (2017). Peningkatan Motivasi dan Hasil Belajar IPA melalui Pembelajaran Inquiri pada Siswa kelas IV SD Negeri Wonoyoso. Jurnal Penelitian Pendidikan, 34(2), 113-120.

Suprihatiningrum, Jamil. (2014). Strategi Pembelajaran Teori dan Aplikasi. Jogjakarta: Ar-ruzz Media.

Taniredja, Tukiran, dkk. 2011. Penelitian Tindakan Kelas. Bandung: Alfabeta.

Yamin, Martinis. 2011. Profesionalisasi Guru dan Implementasi KTSP. Jakarta: Gaung Persada Press.

Yuni, F. (2016). Upaya Peningkatan Hasil Belajar TEMATIK Melalui Model Pembelajaran Teams Games Tournament (TGT) dan Pembelajaran Problem Based Learning (PBL) Siswa Kelas 4 SDN Kutowinangun 12 Salatiga Semester II Tahun Pelajaran 2015/2016 (Doctoral dissertation, Program Studi Pendidikan Guru Sekolah Dasar FKIP-UKSW) 